\title{
A Contrastive Study of Grammaticalization and Degrammaticalization*
}

\author{
Yujuan Feng \\ School of Foreign Languages \\ Southwest Minzu University \\ Chengdu, China
}

\author{
Xianjing Han \\ School of Foreign Languages \\ Southwest Minzu University \\ Chengdu, China
}

\begin{abstract}
Grammaticalization is most frequently conceived as a diachronic process form a process from a less grammatical unit to a more grammatical unit. While the research on degrammticalization has stirred great disputes from its very beginning for the simple reason that it challenges the Principle of Unidirectionality, which is the nucleus of grammaticalization theory. Based on the discussion and analysis in this article, it is beyond doubt that the linguistic evidences of degrammticalization exist in a wide range of languages, and the debate about the existence and feasibility of degrammaticalization is largely a matter of definition and scope among different scholars. Therefore, this thesis intends to probe into the definition, categorization, motivations, and mechanism of both grammaticalization and degrammaticalizaiton based on the previous research in the domain, in an attempt to make a contrastive study between grammaticalization and degrammaticalization in order to shed light on their connections and distinctions.
\end{abstract}

Keywords-grammaticalization; mechanism

degrammaticalization;

\section{INTRODUCTION}

The term "grammaticalization" was coined by Antoine Meillet to be applied to the concept which is still used today. Meillet further expounds that grammmaticalization is not only a process in which a lexical unit gains a grammatical function but also a process in which a grammatical unit assumes a more grammatical function. He puts emphasis on the diachronic perspective. Since Meillet, there has been a broadening in the scope of research related to grammaticalization. As a consequence, it is not easy to find a general definition or a common denominator for grammaticalization, due to the various contents and applications which grammaticalization has today.

The study of grammaticalization has caused great controversy in the linguistic circle from the beginning of its appearance [1]. But there have long been three typical views

*This paper is supported by the "Fundamental Research Funds for the Central Universities, Southwest Minzu University"(Number: 13SQN40), "Sichuan Social Science Planning Project (Special Project of Foreign Language)" (Number:SC16WY029), "Foreign Education Research Project of Sichuan Foreign Language Literature Research Center \& Shanghai Foreign Language Education Press" (Number: SCWYH12-28), and "Teaching Reform Project of SMU"(Number: 2012YB10). concerning that of degrammaticalization: the first one is a little extreme, which regards degrammaticalization only as an individual and isolated linguistic phenomenon to challenge the Unidirectionality Hypothesis of grammaticalization, so both of its motivation and approaches are worth denouncing, with scholars like Börjars, Janda, etc., as the representatives; the second view holds that degrammaticalization is tremendously outnumbered by grammaticalization, so it is not statistically significant and should be ignored, with the leading supporters such as Heine, Claudi \& Hünnemeyer, Kuteva, and so on; the third is slightly different from the previous two completely negative attitudes, and believes that the process of degrammaticalization does exist as a language evolves, but, in contrast to the grammaticalization process, it can be seen as an exception case and does not require extra explanation and research, with such representative linguists as Haspelmath included.

\section{LITERATURE REVIEW}

\section{A. Definition: Grammaticalization vs. Degrammaticalization}

As for grammaticalization, Christian Lehmann provided an explicit definition: grammaticalization is a process leading from lexemes to grammatical formatives. A number of semantic, syntactic and phonological processes interact in the grammaticalization of morphemes and whole constructions [2]. William Croft elaborates the term on earlier discussions of grammaticalization, which he sees as a process by which full lexical items become grammatical morphemes; it is unidirectional and cyclic: grammatical morphemes originate from lexical items, disappear through loss, and reappear when new words become grammatical morphemes [2].

As for degrammaticalization, scholars, such as Heine and Norde, have defined it in different ways, and there has been a great controversy over the nature of that term [3][4]. Some scholars regard it as the reverse mirror process of grammaticalization [5][6]. While others believe that degrammaticalization is equivalent to lexicalization of functional words (such as ups, downs) and affixes (such as isms, -ologies) [7]. But it is a pity that all these definitions fail to clarify the distinctions between degrammaticalization, grammaticalization, lexicalization, and constructionalization, which will be discussed further in detail in the following part. 


\section{B. Connection Between Grammaticalization and Degrammaticalization}

In order to better define and interpret the language phenomenon of degrammaticalization, this article will try to extend the range of degrammaticalization based on the "cline of grammaticality" by Hopper \& Traugott [8]. The following formula is Norde's modification of the cline of grammaticality: $(>\varnothing)$

content word $>$ grammatical word $>$ clitic $>$ inflectional affix

From the perspective of historical linguistics and functional linguistics, Brinton, Hopper and Traugott all hold that grammaticality is not discrete, but rather instead, a continuum from low degree to high degree. That is, from left to right along the cline, from content word, grammatical word, clitic to inflectional affix, the grammaticality rises in turn, and that escalation process of grammaticality is traditionally known as grammaticalization. At the right terminal of the cline, the zero stage, symbolized as " $\varnothing$ ", does not appear in the initial form of cline by Hopper and Traugott, but due to the constant dispute in the academic world that the final stage of grammaticalization is the complete disappearance of any grammatical form, this article puts the zero stage as an independent stage at the right end of the cline. Based on the cline of grammaticality above, Norde specifies degrammaticalization as the opposite process of grammaticalization - the process from right to left[9]. This specification clarifies and justifies the existence of degrammaticalization, the relationship between grammaticalization and degrammaticalization, as well as the evolving process and criteria for degrammaticalization.

However, there are some obvious defects in this specification, which includes inflectional affix but not derivative affixes, and ignores the fact that degrammaticalization is essentially an intrinsic structural change. Therefore, in his "Degrammaticalization" published in 2009, Norde revises the definition of grammaticalization as the increase in the autonomy and meaning change of grams on such linguistic levels as phonology, morphology, semantics, syntax, etc.[4]

\section{MECHANISM OF GRAMMATICALIZATION}

\section{A. Motivation of Grammaticalization}

There are multiple factors in the development of language. Peyrube states that the meanings of the lexical item subject to grammaticalization are usually quite general, for example, verbs like "say", "move" or "go", non-verbs with a specific meaning like "whisper". Therefore, typically, words with more basic meanings or words that are easily accessible tend to be grammaticalized more easily. The reason is that language change is usually motivated by speakers' communicative needs, which are led by human cognition process, which motivates meaning and syntactic change in the most common words.

Hopper \& Traugott believe that pragmatic inferencing is a motivation for grammaticalization. When the speaker and hearer negotiate meaning in communicative situations, the speaker's role is based on the economical principle, which means the speaker always tries to use least possible words to clearly express most possible information or to maximize the sphere of usage of one specific language form. One classic example of this is "be going to", which gains the meaning of futurity through grammaticalization.

Cognitive factor is also regarded as the core motivation in the meaning evolution. Metaphor and metonymy are of remarked significance in human cognition process. Metaphor means the understanding of one concept in terms of another, sometimes responsible for language change. Take "Sally is a block of ice" for an instance. There is apparently no inherent similarity between Sally and ice. What brings these two concepts together is the perception, based in part on culture and in part on feelings that all human beings share -ice is freezing cold and Sally is someone who cannot make people around her warm. Through metaphor the abstract notion of personality is conceptualized as something concrete. Lakoff \& Johnson describe metonymy in cognitive terms as a process which allows us to conceptualize one thing by means of its relation to something else, for instance, from "cradle" to "grave". What does this phrase imply? It means from birth to death. The reason is that new-born babies are put in cradles, and thus, over a long time, these two concepts are closely related. Finally, cradle gains the meaning of birth. Through the process of metonymy, we substitute birth for cradle. The difference between metaphor and metonymy is that metaphor involves two completely different concepts while metonymy involves two closely related concepts.

Intra-language factor is another stimuli for language change. Syntactic environment can influence the process of grammaticalization. A verb is usually in the central position of a sentence, which is to express specific movements. More often than not, when a verb acts as a secondary verb in a sentence, and its syntactic position is relatively settled, it can easily become a verb complement, and eventually a grammatical marker.

\section{B. Internal Mechanism}

Analogy, by definition, is the extension of syntactic rules. It is a source of language change that involves the generalization of a regularity on the basis of the inference that if elements are alike in some respects, they should be alike in others as well, for example, "bring" becomes "brung" by analogy with "ring" and "rung". Compared with analogy, the changes to language structure are not so obvious in the process of reanalysis.

Reanalysis, by definition, is a source of language change that involves an attempt to attribute an internal structure to a word that was formerly not broken down into component morphemes. It does not instantly change the surface manifestation of a sentence, but it often leads to boundary creation, shift and loss, which can be shown as follows: (A, $\mathrm{B})(\mathrm{C}) \rightarrow(\mathrm{A})(\mathrm{B}, \mathrm{C})$ :

They have tried and failed to contact her. (1)

I will try and contact her. (2)

I will try to contact her. (3)

In example (1), the structural boundary is [tried][and][failed to contact], which are two respective movements; in example 
(2), the structural boundary is [try and][contact], which is to say that [try and] is reanalyzed into a new component and [try] and [and] are phonologically bound together. What's more, no adverbs can be inserted between these two words. Thus, compared with [try to] in example (3), [try and] becomes an auxiliary.

Relationships between analogy and reanalysis can be demonstrated as: analogy focuses on the surface or external structure and makes it possible for grammar rules to be applied to various language structures while reanalysis focuses on the deep or internal structure and gives rise to new language structures or grammar forms. However, neither of these two mechanisms works independently during the process of grammaticalization. Analogical extension is the key process to put the reanalysis down the path to grammaticalization.

\section{External Mechanism}

Unidirectionality, as well as semantic and phonological reduction are referred to as the external mechanism of grammaticalization[10]. April McMahon clarifies these traits as follows: words from major lexical categories, such as nouns, verbs and adjectives, become members of minor grammatical categories such as prepositions, adverbs and auxiliaries, which in turn may become affixes. Full words, with their own lexical content, thus become form words, which simply mark a particular construction; this categorial change tends to be accompanied by a reduction in phonological form and a bleaching of meaning. Thus, grammaticalization is not only a syntactic change, but a global change affecting the morphology, phonology and semantics as well.

We can take following three sentences as an example to further illustrate these traits of grammaticalization:

\section{I have a book. (4)}

I have to read a book. (5)

I have had a book. (6)

Here, "have" in the example (4) is a content word; in example (5), "have" doesn't act alone and is used as an incomplete auxiliary verb; in example (6), "have" is a perfective marker and used as a complete auxiliary verb. Auxiliary verbs such as "have" and "will" are transformed from content words and are used together with the words in front of them. Phonological reduction can also be caused by this process, for example, I will > I'll. The process of grammaticalization can be demonstrated in the following formula, which well manifests the principle of unidirectionality: verb

Full verb > incomplete auxiliary verb > complete auxiliary

\section{MECHANISM OF DEGRAMMATICALIZATION}

In his book "Degrammaticalization", Norde divides the procedures of degrammaticalization into three categories: degrammation, deinflectionalization and debonding, with the first one being primary degrammaticalization and the last two being secondary degrammaticalization. Primary degrammaticalization refers to the transformation of a functional word into a complete lexical item, while secondary degrammaticalization refers to the transformation of bound morphemes (inflectional affix, derivational affix and clitic) into forms of low grammaticality. The following analysis into different levels of language change by Andersen can help better understand Norde's classification of degrammaticalization [11].

\section{CONTENT LEVEL}

The change from grammatical meaning to lexical meaning is usually a process in which functional words are transformed into major lexical categories, such as a verb or a noun, so as to obtain the typical morphosyntactic features of the main lexical categories and enhance the original semantic features. Therefore, the process can also be understood as a matter of resemanticization. Degrammaticalization at the content level is a primary grammaticalization, which is actually "degrammation" as defined by Norde.

\section{A. Content-syntactic Level}

This is a change from a more grammatical form to a less grammatical form, which is accompanied by a reduction in grammatical meaning. Degrammaticalization at the contentsyntactic level is a subcategory of secondary grammaticalization, or "deinflectionalization" as defined by Norde.

\section{B. Morphosyntactic Level}

It is a change from a bound morpheme (affix, clitic) to a free morpheme. Degrammaticalization at morpho-syntactic level is another subcategory of secondary grammaticalization, and Norde terms it as debonding.

From the above discussion it is easily seen that there has long been a rejection against the research into degrammaticalization in the academic circle. The reason is that degrammaticalization has shaken the core hypothesis of grammatical evolution, that is, the unidirectionality mentioned above. For historical linguists, to regard the unidirectionality hypothesis as a universal truth without exception provides a typical neogrammarian approach of interpretation; while the recognition of the existence of linguistic phenomena of grammaticalization would degenerate the unidirectionality from an undeniable principle to a statistical hypothesis, which would force them to abandon such a powerful tool to explain the language evolution. But ignoring and rejecting the linguistic phenomena of degrammaticalization which do exist is clearly not a wise move, as Van der Auwera has once said,

"Meanwhile, however, there is general consensus that degrammaticalization does exist. There is a further consensus that it is much rarer than grammaticalization. It is difficult to quantify just how rare a phenomenon it is. ... So we can begin to study it in tis own right, not just as a falsification of the claim that it would not exist or as supporting the more general critique that grammaticalization theorists pursue something by far not as exciting as they think." [12] 


\section{CONCLUSION}

Grammaticalization is a complicated phenomenon and from examples listed above, we reach the conclusion that its process is closely related to human cognitive process and pragmatic use. It is acknowledged that some grammatical items derive from lexical items over time through analogy and reanalysis, thus the meanings of grammatical items could be better understood due to its remarkable relevance to the original meaning. In contrast, as a universal linguistic phenomenon, degrammaticalization has aroused more and more attention in the academic world, and caused widespread controversy in the meantime. The focus of the dispute lies in the conflict between degrammaticalization and unidirectionality hypothesis which is the most important principle in the grammaticalization theory. Among the three subtypes of degrammaticalization discussed in this article, degrammation poses the greatest challenge to a lot of traditional viewpoints of grammaticalization. The reason is that degrammation involves changes in every level of language and can be deducted from pragmatic inferencing, while the traditional concept holds that pragmatic inferencing can only be used to trigger grammaticalization rather than degrammaticalization. Debonding is of the highest frequency and the most variety among the three subtypes of degrammaticalization, because it involves the three different types of bound morphemes - inflection affix, derivational affix, and clitic. Since the semantic and grammatical functions are not changed, the debonding of inflection affix and clitic is the least recognized type of degrammaticalization.

Based on the discussion and analysis in this article, there is no denying for the existence of degrammaticalization as a universal language phenomenon, and the current debate over the feasibility of degrammaticalization only lies in the discord in its definition and scope among different scholars. However, it is regrettable that, although the foreign linguistic circles are enthusiastic for the study of degrammaticalization, this unique language phenomenon is included in the domain of lexicalization among Chinese linguists, and has not formed been no systematic research paradigm so far. Therefore, the study of degrammaticalization between Chinese and other languages from the perspective of contrastive linguistics will be the direction and goal of the author in the near future.

\section{REFERENCES}

[1] Norde, Muriel. Degrammaticalization: Three Common Controversies // Grammaticalization: Current Views and Issues. Stathi, Ekatenrini, Elke Gehweiler and Ekkehard König (eds.), 2010, pp. 123-150.

[2] Campbell, Lyle \& Janda, Richard. Introduction: Conceptions of Grammaticalization and Their Problems. Language Sciences, 2001, 23(2-3), pp. 93-112

[3] Heine, Bernd. On Degrammaticalization // Historical Linguistics (Selected Papers from the 15th International Conference on Historical Linguistics. Melbourne, 13-17 August, 2001), Barry J. Blake \& Kate Burridge (eds.). Amsterdam/Philadelphia: John Benjamins Publishing Company, 2003, pp.163-179.

[4] Norde, Muriel. Degrammaticalization. Oxford: OUP, 2009.

[5] Lehmann, Christian. Thoughts on Grammaticalization. Munich: Lincom, 1995, pp. 19.

[6] Haspelmath, Martin. On Directionality in Language Change with Particular Reference to Grammaticalization // Up and Down the Cline -
The Nature of Grammaticalization, Olga Fischer, Muriel Norde \& Harry Perridon (eds.), 2004, 17-44.

[7] Ramat, Paolo. Thoughts on Degrammaticalization. Linguistics, 1992(30), pp. 549-560.

[8] Hopper, Paul, J. \& Elizabeth Traugott. Grammaticalization. Cambridge: CUP, 2003, pp. 7.

[9] Norde, Muriel. Demarcating Degrammaticalization: The Swedish Sgenitive Revisited. Nordic Journal of Linguistics, 2006(29-2), pp. 202.

[10] Mingyou, Xiang. A Study of the Grammaticalization on English and Chinese. Beijing: Higher Education Press, 2014.

[11] Andersen, Henning. 2006. Grammation, Regrammation and Degrammation - Tense Loss in Russian. Diachronica 23(2), pp. 231258.

[12] Auwera, Johan van der. More thoughts on Degrammaticalization//New Reflections on Grammaticalization. Ilse Wischer \& Gabriele Diewald (eds.), 2002, pp. 22-23. 